\title{
INFLUENCING FACTORS TO LOGISTICS CENTRE FORMATION - A STUDY OF VIETNAM-BASED LOGISTICS SECTOR
}

\author{
Ho Thi Thu Hoa ${ }^{1 *}$, Nguyen Van Khoang ${ }^{2}$, Tran Quang Dao ${ }^{3}$, Le Van Thanh ${ }^{4}$, Chu Thi Hue ${ }^{5}$, Nguyen Huynh Luu \\ Phuong ${ }^{6}$
}

${ }^{1,2,35,6}$ Ho Chi Minh City University of Transport, Vietnam, ${ }^{4}$ Division of Project Management, JSC Sai Gon Hiep Phuoc Port, Vietnam.

Email: ${ }^{1 *}$ hoa.ho@ut.edu.vn, ${ }^{2}$ khoang_kt@hcmutrans.edu.vn, ${ }^{3}$ dao.tran@ut.edu.vn, ${ }^{4}$ levanthanh@gmail.com, ${ }^{5}$ hue.chu@ut.edu.vn, ${ }^{6}$ phuong_kt@hcmutrans.edu.vn

Article History: Received on $03^{\text {rd }}$ July 2019, Revised on $02^{\text {nd }}$ February 2020, Published on $28^{\text {th }}$ February 2020

\begin{abstract}
Purpose of the study: The paper tries to model dynamic interactions of factors that contribute to the logistics center building. Conducting the desk review and expert consultation, the causality of the factors is systemized in a form of Causal Loop Diagram using the System Dynamics approach.

Methodology: System Dynamics (SD) is an approach for studying interlinked behaviors within a system and reflects the interactions of feedback loops. Compared to other approaches, SD demonstrates the real world by using factors and stocks for components and feedback loops for inter-relationships among them. SD model qualitatively illustrates the causal relationship among factors that influence the building of the logistics center.
\end{abstract}

Main Findings: A combination of four different sub-systems, using a questionnaire survey conducted with logistics service users and providers to sort out the high scored factors. Besides, the survey also helps to study the practical conditions and characteristics in showing the demand, the trend, and the development of logistics centers in Vietnam.

Applications of this study: Logistics centers (LCs) can be considered as a depot for vehicles where drivers and managers of vehicles are supposed to maintain, repair vehicles, and adjust vehicle operation schedules.

Novelty/Originality of this study: As defined by the scope of the project, the SD model provides a qualitative demonstration of the interaction among factors. The built model gives a systematic insight into how factors link to each other.

Keywords: Logistics Centers, Influencing Factors, System Dynamics Model, Causal Loop Diagram, South East Region.

\section{INTRODUCTION}

The term "logistics center" (LC) has become prevalent around the world in the context of globalization, technological development, accelerating cross-border connectivity among countries and competitive optimization solutions among enterprises (Ruina, Zhong, Peiyong, \& Haobin, 2019). Though, there is not yet a consensus definition of LC among countries. Particularly, it is called "freight villages" in the UK, "Plate Forme Logistique" in France, "Interporto" in Italy and "Transport center" in Denmark. "Logistics center" is popular in Japan, Singapore, China and the US (Lagorio, Pinto, \& Golini, 2016) (Yang, Song, Shen, Ghuktomova, \& Xu, 2017).

The most common and widely accepted among researchers, which is defined by Europlatforms (European Association of Freight Villages), an LC must be a location that activities related to transport, logistics, distribution of domestic and international commodity implemented by different actors. They can be cargo owners or users of a facility such as a warehouse, office, marshaling area, etc (Supply et al., 2019). There is a crucial attribute of an LC to have facility and equipment and to be connected to different transport modes like railway, road, sea, inland waterway and airway(Kumar, Singh, \& Kumar, 2018). Reviewing other studies, LC can be comprehensively defined as a major system of area and international macro logistics system participating in commodity flows by logistics chain and LC is a connecting point between many transport modes and concentration of commodity flows distribution (Schliwa, Armitage, Aziz, Evans, \&

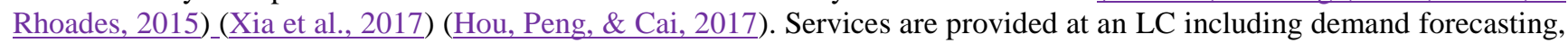
purchasing, production planning, manufacturing inventory, warehousing, material handling, packaging, order processing, customers service, preparation of commercial and customs documents, reception of export licenses, insurance, and so on (Yu \& Wu, 2017).

One of the popular case studies of LC is the one in Bremen (Germany), which is founded in 1985. In the center, the transport network is provided in high-quality standards with the port model, intermodal transport, and railway. However, this center is then be assessed with some drawbacks, such as lack of land available for future development due to its closeness to residential are (Pratiwi \& Furusho, 2019). Besides, a high rent price is also a challenge for service provider companies in the center. Another case study is the Singapore logistics center (Hidayati, Karim, Haqimin, Salleh, \& Harun, 2019)._Singapore port is connected with 600 other ports in 123 nations with the support of 200 shipping lines (Montwiłk, 2016)._This center has become a favorable destination for companies in various sectors, such as AAvaya, Diageo, Dell, Hewlett Packard, Infineon, LVMH, Novartis, ON S bánucter, Panasonic, Siemens with the provision of 3PL services, ranging from air transport, customs clearance, sea transport, warehousing, customized logistics solutions or value-added services (Qaiser, Ahmed, Sykora, Choudhary, \& Simpson, 2017)_(Aparna \& Ramakrishna, 2018).

802 |www.hssr.in

(C) Hoa et al. 
In the context of Vietnam, logistics is a rising star in the country thanks to its contribution to the economy and the notion of becoming prevalent among people awareness during the last decades (Fan, Wang, \& Kang, 2018). According to the Logistics Performance Index (LPI) in 2018 published by the World Bank, Vietnam ranked 39 out of the 160 investigated countries. Among emerging demands, that of building a logistics center for Ho Chi Minh city and its vicinity becomes a mission of the city and administrative ministry in charge - Ministry of Industry and Trade, Vietnam. The Decision 200/QD-TTg endorsed by Prime Minister on February 14, 2017, raises the importance of an action plan for improvement of competitiveness and development of Vietnam's logistics services by 2025 (Zainal \& Jeevan, 2019). The decision asserts that logistics plays a role as an important service sector of the national economy, helps connect and foster social-economic development of the whole country as well as provinces and improves the competitive ability of the economy (Nguyen \& Sarker, 2018).

Developing logistics service brings to us highly added value, intensive support to manufacturing, import-export and trading sector, develop transport and information technology infrastructure, facilitate the country's strategic location in order to be an important logistics hub in the region (J Jeevan, Salleh, Loke, \& Saharuddin, 2017). Therefore, the government supports and creates incentives to boost the competitiveness and logistics service of the country (Sivaraja, Sakthivel, \& Warke, 2018). Based on that approach, six missions are proposed including improving policy and laws related to logistics service, improving logistics infrastructure, improve the ability of enterprise ability and service quality, developing logistics service market, educating and improving awareness and quality of logistics human resources (Yoon \& Doan, 2018).

Besides, The Decision 1012/QĐ-TTg by Prime Minister about the development plan for building a logistics center system in Vietnam until 2020, vision 2030 (M. Li, 2016). The official Vietnam Logistics Report 2018 of Ministry of Industry and Trade realized some existing barriers of developing LC In Vietnam, including (1) lack of LC at national level and the term LC is not clearly defined in Vietnam's context; (2) the role of the government in managing LC type I and II is not well defined, lack of policy and regulations regarding developing LC; (3) ability of providing services, competitiveness and logistics connectivity between Vietnam and region is still limited; (4) system of criteria to classify LC is not well defined and statistical data about LC is not synchronous (Gligor, Tan, \& Nguyen, 2018).

In response to the action plan of the government, the research aims to propose an analytical framework for considering important factors that contribute to the development of the logistics center in Vietnam using the System Dynamics (SD) approach (Gobinath, Senthilkumar, \& Beemkumar, 2018). This approach is based on observing the development of LC as a system and attempts to model influencing factors relating to the development. Reviewing the SD approach from literature, our world is full of systems in which components or participants are connected to each other (Dinh \& Im, 2016). Any changes, which can be in number or attribute, of a component will result in changes in other ones and the whole system as well. According to (Golroudbary \& Zahraee, 2015), System Dynamics (SD) examines factors within a system and their connections and provides researchers with a visual illustration and analysis framework of the structure or dynamics of a system (Noorul, RAHMAN \& Noor Apandi OSNIN, Rudiah MD HANAFIAH, Mohd Rahimi ABDUL HALIM, Shahriman ABDUL HAMIDc, 2019). A causal loop diagram (CLD) is one among tools in SD theory and it shows the reason-result relationship among factors within the system (Acharya, Nanda, Panda, \& Acharya, 2018). For modeling, the terms such as feedback, arrow, polarity, variables, delays, and feedback loop are mentioned in CLD when discussing on system thinking. Variables might be in forms of nouns or noun phrases, arrows used for illustrating mutual effects between variables are called feedback or causality (Qu et al., 2017).

There are two types of feedback among factors, those moving in the same trend and reverse trend. The former means an increase in factor A leads to the same trend in factor B, e.g. the interest rate of a bank and the saving in an account. Regarding the latter, factors that have a reverse relation showing an increase in factor A leads to a decrease in factor B. Take the number of population and air quality in a city as an example. When variables and arrows create a feedback loop in the form of a closed circle, it contains an odd number of (-) causal links and is called Negative or Balancing. If there is an even number of minus polarity (-) or not at all, the loop is called Positive or Reinforcing loop. (Achachlouei \& Hilty, 2015) suggests having a qualitative analysis is then required for a comprehensive view of the problem and coming up with ideas for solutions.

Thus the paper tries to model dynamic interactions of factors that contribute to the logistics center building. Conducting the desk review and expert consultation, the causality of the factors is systemized in a form of Causal Loop Diagram using the System Dynamics approach.

\section{METHODOLOGY}

System Dynamics (SD) is an approach for studying interlinked behaviors within a system and reflects the interactions of feedback loops as well as delays in the system (Luthra \& Mangla, 2018). Compared to other approaches, SD demonstrates the real world by using factors and stocks for components and feedback loops for inter-relationships among them (Yesilyurt, 2018).

There is a need for building a systematic framework that helps us observe the interaction among factors affecting the logistics center. Defined by the scope, the aim of this study is to formulate the SD model that qualitatively illustrates the causal relationship among factors that influence the building of the logistics center (Witkowski, 2017). 
Step 1: Conducting desk review and consult experts for a list of factors related to the construction process of a logistics center;

Step 2: Conducting a questionnaire-based interview with cargo owners/logistics service users (CO) and logistics service providers (LSP) for their assessment of important factors together with causality among factors;

Step 3: Using Analogic software to form the causal relation using the result from the previous step.

To form the model, 25 factors which have the highest consensus results from questionnaire and interview with respondents are then listed below. These factors are grouped into four sub-systems including Criteria of (1) cost of business operation, (2) customer satisfaction, (3) work attributes, (4) policy - law - economics - social issues. The sub-systems are then synchronized to build a comprehensive illustration of the interactive system later on (Kamble, Gunasekaran, \& Gawankar, 2018).

Survey methodology and sampling frame: The process to do this research followed the steps as indicated in Figure 1. A questionnaire was designed to collect primary data from both Vietnam logistics service providers (LSPs) and Vietnam logistics service users - cargo owners in terms of significant issues related to the requirement of a logistics center (Al Sahlani, \& A. Eidan, 2018). Collected data are processed and analyzed by SPSS software. The details of the questionnaire survey and data analysis are presented in Table 1 (Wang \& Nguyen, 2017).

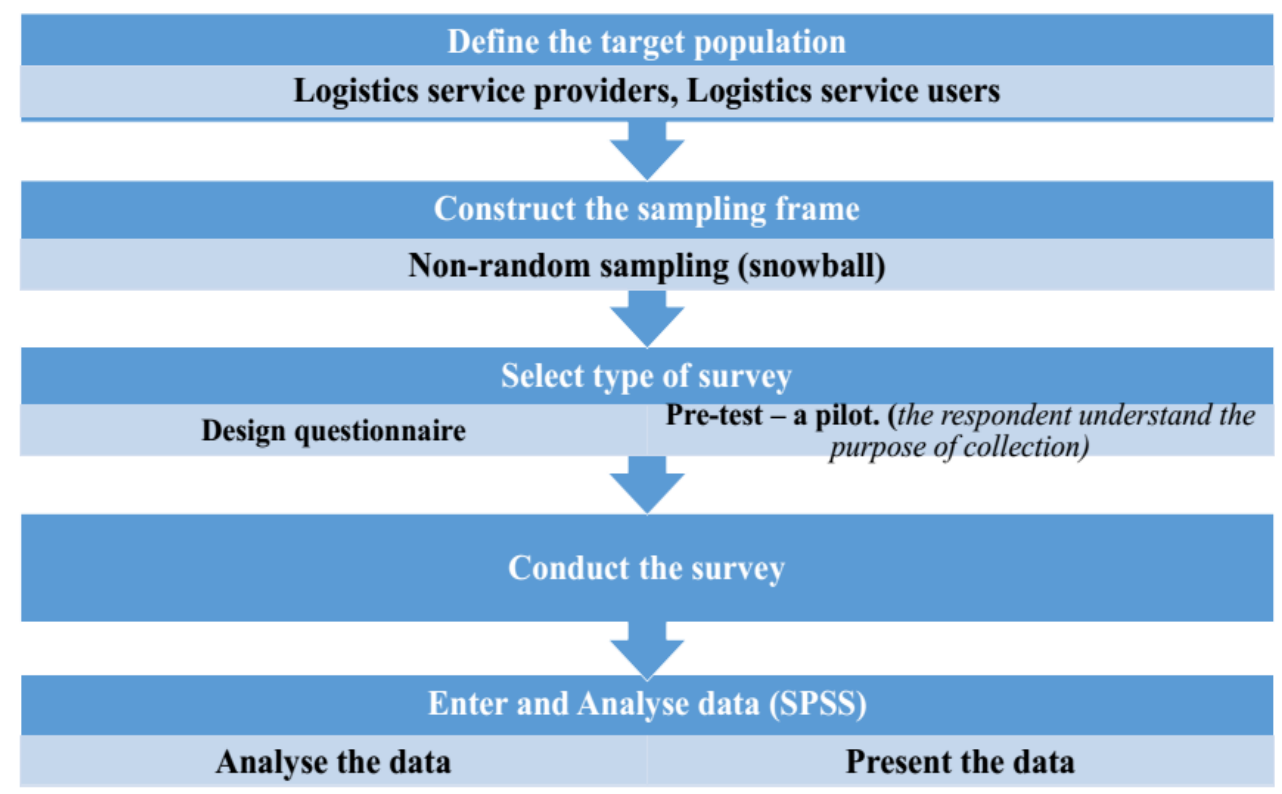

Figure 1: The research processes

Table 1: The detail of the questionnaire survey and data analysis

\begin{tabular}{ll}
\hline Items & Contents \\
\hline Survey method & Questionnaire survey \\
\hline Sampling method & Non-random sampling (snowball) \\
\hline Assessment method & Quantitative, qualitative \\
\hline \multirow{2}{*}{ Types of response format } & - Yes/No \\
& - Multiple choices \\
\hline Survey time & - Open-ended \\
\hline Number of respondents & June-August, 2019 \\
\hline Data processing and analysis tools & Logistics service users: 39 \\
\hline & Logistics service providers: 46 \\
Reliability analysis & SPSS (Statistic Package for Social Science) \\
& Cronbach Alpha factor $(\alpha):$ \\
& $0.6 \leq \alpha<0.7:$ Acceptable \\
\hline
\end{tabular}

Source: Ho, Thi Thu Hoa (2019) Research project DT194005 "A research on modeling logistics center connecting to multimodal transport network - a case applied for Southeast of Vietnam (Ho Chi Minh City and neighboring provinces”. 


\section{RESULTS AND DISCUSSION}

\section{Factors influencing logistics center demand}

Reviewing research of (Fontes \& Freires, 2018; Achachlouei \& Hilty, 2015) and consulting experts' opinion; 32 questions are selected for survey, of which 25 that are highly agreed and divided into four groups, including cost of business operation, customer satisfaction, work attributes, policy - law - economics - social issues (see Table 2). Each group plays roles as sub-systems creating a comprehensive system later on.

Table 2: System of criteria chosen for analysis of their impacts on the formation of logistic center (Qu et al., 2017)

\begin{tabular}{|c|c|}
\hline Criteria & $\begin{array}{l}\text { Evaluation of enterprises (from medium to high) } \\
\text { on impacts of criteria on logistics center } \\
\text { formation }\end{array}$ \\
\hline \multicolumn{2}{|l|}{ Criteria of cost of business operation } \\
\hline Cost of transport & $100.0 \%$ \\
\hline Cost of warehouse & $82.6 \%$ \\
\hline Cost of inventory & $87.0 \%$ \\
\hline Cost of production & $95.2 \%$ \\
\hline Cost of value-added activities & $91.0 \%$ \\
\hline Cost of retrieval, recycle and treatment. & $65.2 \%$ \\
\hline Cost of information analysis & $85.0 \%$ \\
\hline \multicolumn{2}{|l|}{ Criteria for customer satisfaction } \\
\hline Customer satisfaction on products' features & $100.0 \%$ \\
\hline Quality of packing & $100.0 \%$ \\
\hline Time of meeting demand & $91.6 \%$ \\
\hline Price of product or service & $95.7 \%$ \\
\hline Convenience & $95.7 \%$ \\
\hline Aftersales services & $76.3 \%$ \\
\hline \multicolumn{2}{|l|}{ Work attributes } \\
\hline Complexity of work & $95.7 \%$ \\
\hline Outsourcing & $74.0 \%$ \\
\hline $\begin{array}{l}\text { Optimization of the working procedure to improve } \\
\text { efficiency }\end{array}$ & $95.7 \%$ \\
\hline Specialising job & $95.5 \%$ \\
\hline Application of sharing economy & $72.8 \%$ \\
\hline \multicolumn{2}{|l|}{ Policy - law - economics - social issues } \\
\hline Favourable geographical location & $78.3 \%$ \\
\hline Support and encourage from authorities & $77.3 \%$ \\
\hline Incentives in terms of interest rate and loan & $81.9 \%$ \\
\hline Potential for development & $100.0 \%$ \\
\hline Human resource & $90.9 \%$ \\
\hline
\end{tabular}

\section{The sub-system of business operation factors}

This section analyses the first sub-system related to costs. Transport cost and production cost are those are influenced by other costs. An increase in fuel cost leads to a similar trend in the mentioned ones. When the waiting time increases, transport and warehousing cost increase together with the operation (Bukova, Brumercikova, Cerna, \& Drozdziel, 2018). In order to reduce the transport cost, a common solution that enterprise interviewers answered is outsourcing the trucking crew. This helps them to save the investment budget; whereas, trucking partners are able to utilize vehicles and tackle idling time with their driver-partner network. As an increase in production cost reduces competitiveness, the consumption rate decreases (Golroudbary \& Zahraee, 2015). Cost related to value-added activities rises in correlation with the consumption rate because the number of products needs to be processed before delivery increases (Barata, Rupino Da Cunha, \& Stal, 2018). Among the costs, that related to information processing is intensively connected to other ones within a business operation (Figure 2) (Sivaraja et al., 2018).

\section{The sub-system of customer satisfaction factors}

There are a number of factors that contribute to the satisfactory level of customers (Zhang, Jiang, Hu, \& Pan, 2017). As survey results, the most influencing factor is timeliness. In order to meet customer's requirements of on-time delivery, the company is likely to increase transport and warehouse cost, as this time the operation is not cost-centered but customercentered (Figure 3)(Garza-Reyes, Villarreal, Kumar, \& Molina Ruiz, 2016). 


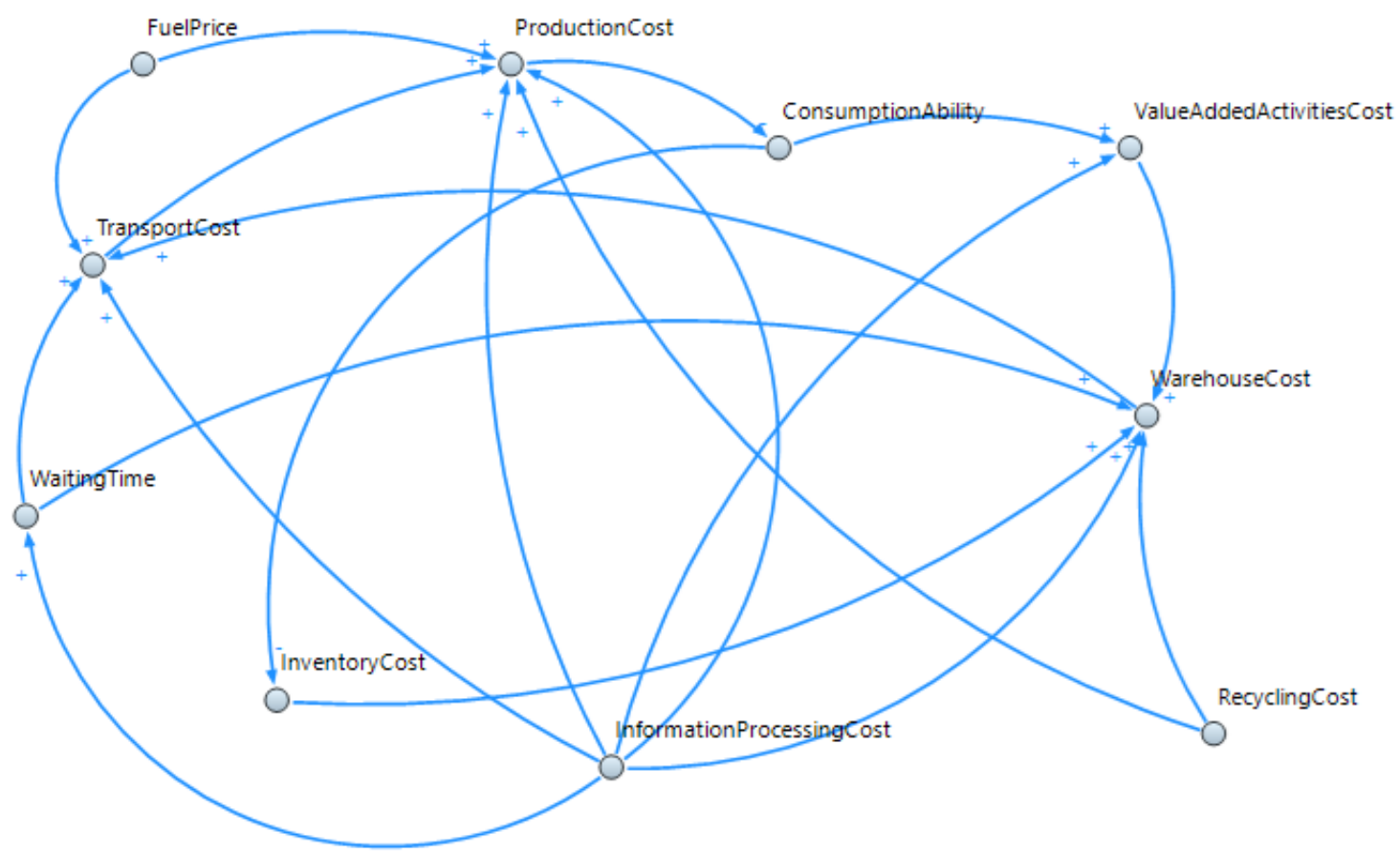

Figure 2: The sub-system of operation cost (Huber, Klauenberg, \& Thaller, 2015)

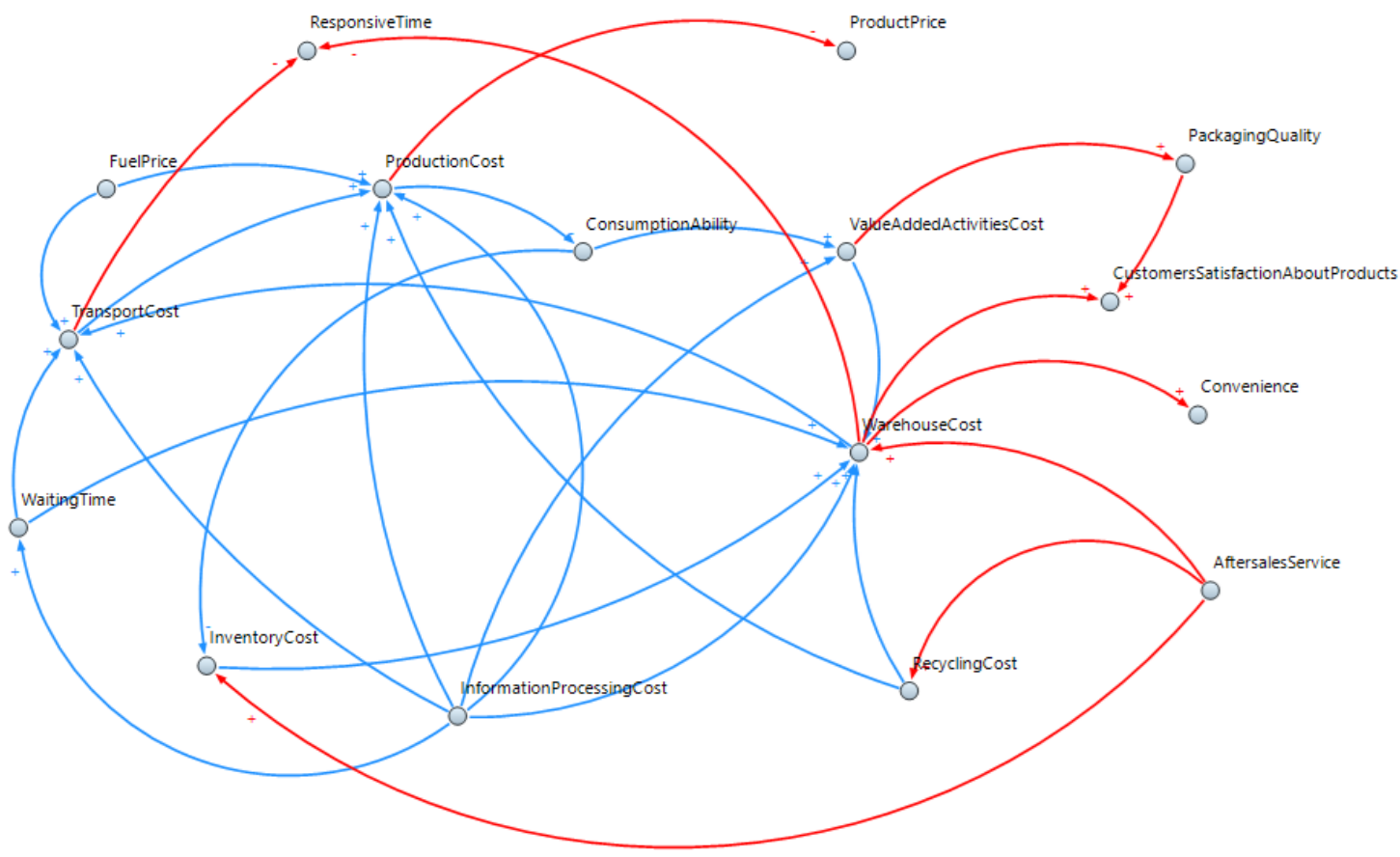

Figure 3: The sub-system of customer satisfaction (red arrows) (Kaewunruen, Sussman, \& Matsumoto, 2016)

By sending out more couriers for meeting timelines, recruiting more personnel and stocking more products for the desire of availability enhancement of distribution network (Jagan Jeevan, M.R, A.H, G.K, \& T.M.H, 2018). Among those logistics activities, warehouse cost connects remarkably with the satisfaction of customers as an increase in the time of checking and screening, labelling and packaging products carefully before delivery.

\section{The sub-system of work attributes factors}




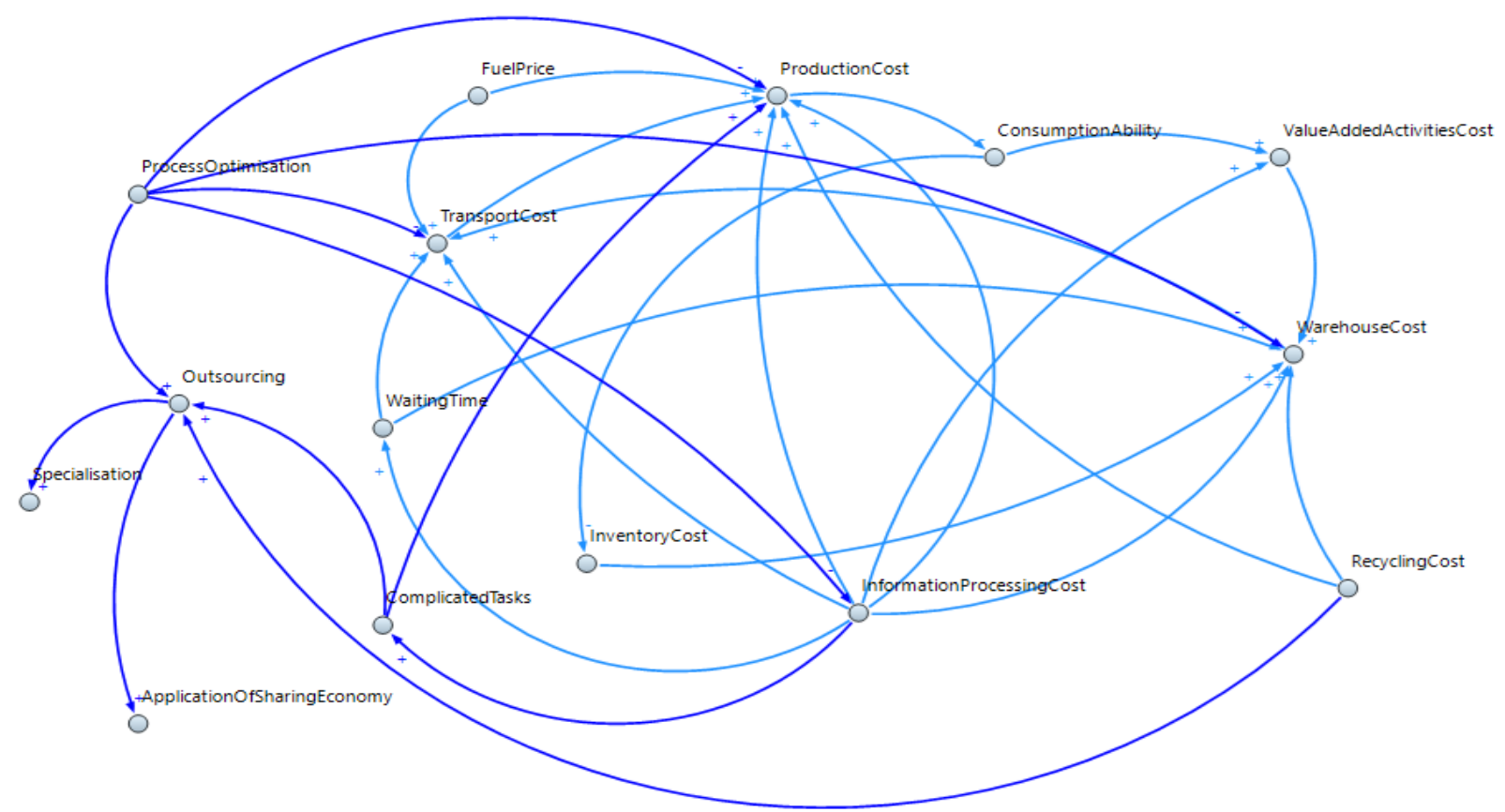

Figure 4: The sub-system of task attributes (marine arrows) (Panigrahi, Kar, Fen, Hoe, \& Wong, 2018)

Optimization of operation in firms will lead to a reduction of a bunch of logistics costs. The higher the level of optimization is, the lower costs are (Salleh, Alias, Jeevan, Hanafiah, \& Ngah, 2019). The more complex work procedure leads to higher production costs due to higher demand in the workforce, machines, fuel, materials as well as time consumption. The complexity of work also raises the need for outsourcing a number of activities, then leads to a better specialization level of the enterprise. Aiming to optimize the working procedure, logistics companies tent to outsourcing tasks to partner ones because the latter is likely to have a higher concentration of task achievement and specialization in a particular number of serviced tasks, such as trucking, customs clearance or customs declaration (Chen, Tabssum, \& Nguyen, 2019). The need for outsourcing enterprises' activities creates the aspiration of having a logistics center to meet the need (Figure 4).

\section{The sub-system of policy - law - social economics factors}

The formation of a logistics center is not only affected by the social need (need from logistics service providers and user companies) but also other social economics has driven factors such as the future potential for development, supports, and subsidies from the government and financial organization. In the context of Vietnam, the government supports and highly appreciates the development of the logistics sector (Figure 5) (Yaqiong, Lei, LEE, \& Xin, 2018). To be specific, Decree 163/2017/NĐ-CP for logistics service business and Directive No. 21/CT-TTg about implementing solutions for reducing logistics costs and effective connection of transport infrastructure are among legal documents expressing the political will of the government to support logistics center (Hazen \& Ellinger, 2019).

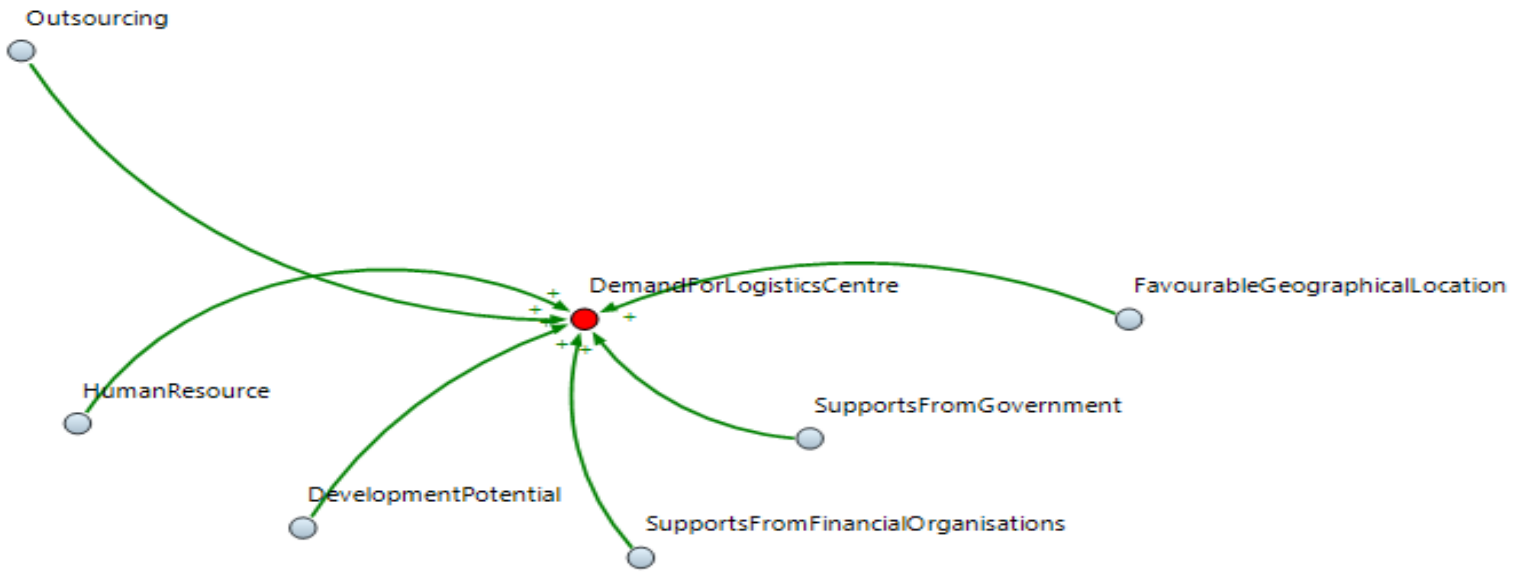

Figure 5: The sub-system of policy -law-social-economics (green arrows) (Panigrahi et al., 2018) 
Also, supports with a soft loan from banks as observed in the market are among the financial aspects required to make the logistics center possible (Quandt, Beinke, Ait-Alla, \& Freitag, 2017). Besides, a good location is also a factor impacting the formation of the logistics center (Guo, Shen, Choi, \& Jung, 2017). In the context of Vietnam, provinces, and cities like Ba Ria-Vung Tau, Da Nang or Hai Phong can make the most of their favorable geographical conditions for developing logistics sectors, serve industrial zones and support the other provinces in their vicinity (Figure 6) (Rahman, Saharuddin, \& $\underline{\text { Rasdi, 2014). }}$

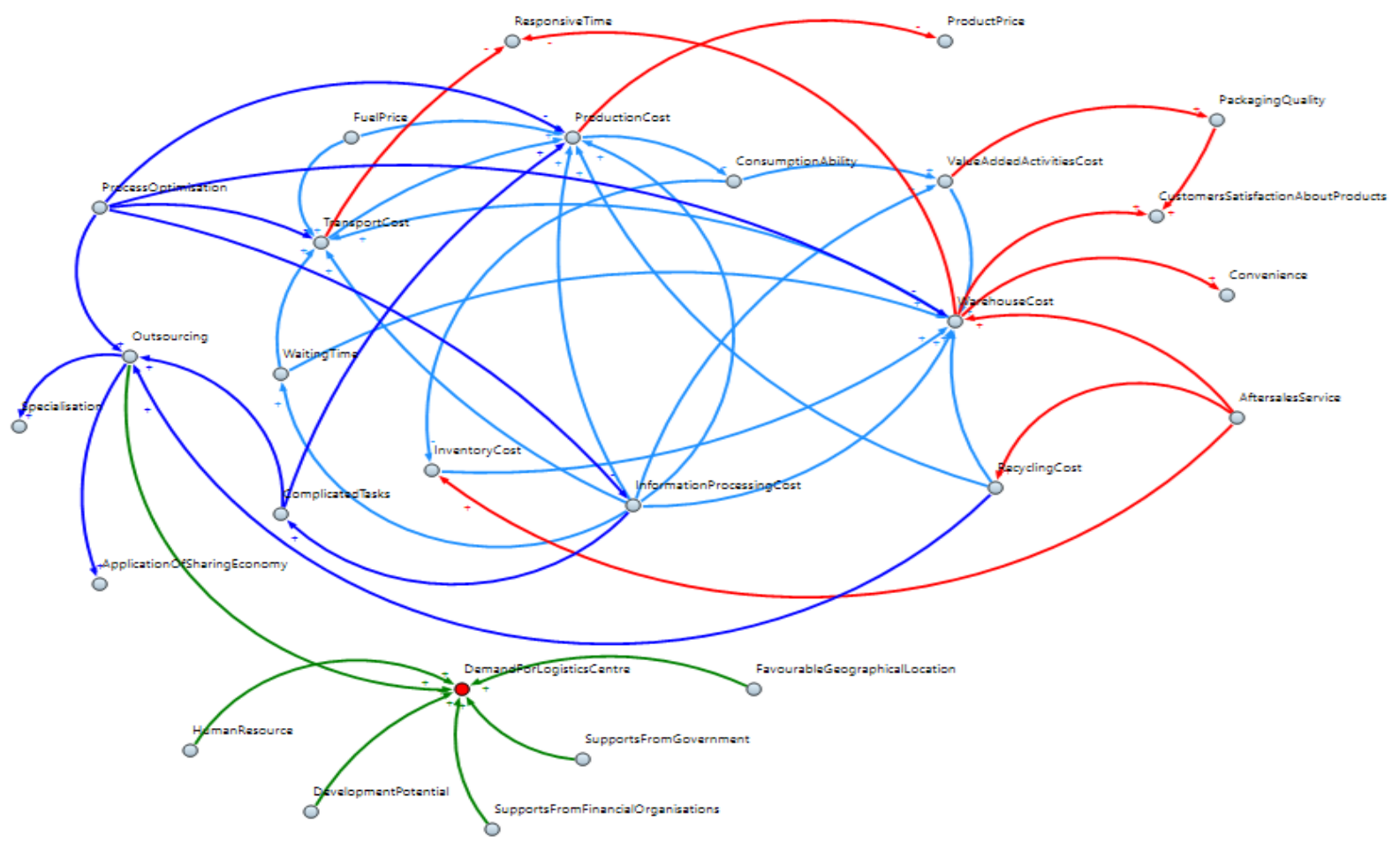

Figure 6: System Dynamics of influencing factors for a logistics center

In addition to that, the SD approach is also utilized for analyzing the influence of the multimodal network on the operation of a logistics center (Y. Li et al., 2018).

Table 3: Criteria system for evaluating the influence of multi-modal transport network on the operation of LC

\begin{tabular}{ll}
\hline Criteria & The average score of companies \\
\hline Multi-modal transport & \\
\hline Number of modes connecting to the center & $100 \%$ \\
\hline Distance from LC to transport modes & $100 \%$ \\
\hline $\begin{array}{l}\text { Connecting the ability of LC to transport nodes and } \\
\text { market }\end{array}$ & $98 \%$ \\
\hline Infrastructure condition of transport modes & $82 \%$ \\
\hline Policy related to transport modes & $65 \%$ \\
\hline Transport operation efficiency of LC & \\
\hline Transport time & $92 \%$ \\
\hline Quality and safety of the products & $81 \%$ \\
\hline The diversity of transport service & $96 \%$ \\
\hline Transport flow among modes & $60 \%$ \\
\hline $\begin{array}{l}\text { Connectivity between manufacturing and } \\
\text { consumption }\end{array}$ & $58 \%$ \\
\hline Transport cost & $98 \%$ \\
\hline
\end{tabular}

Source: survey results 


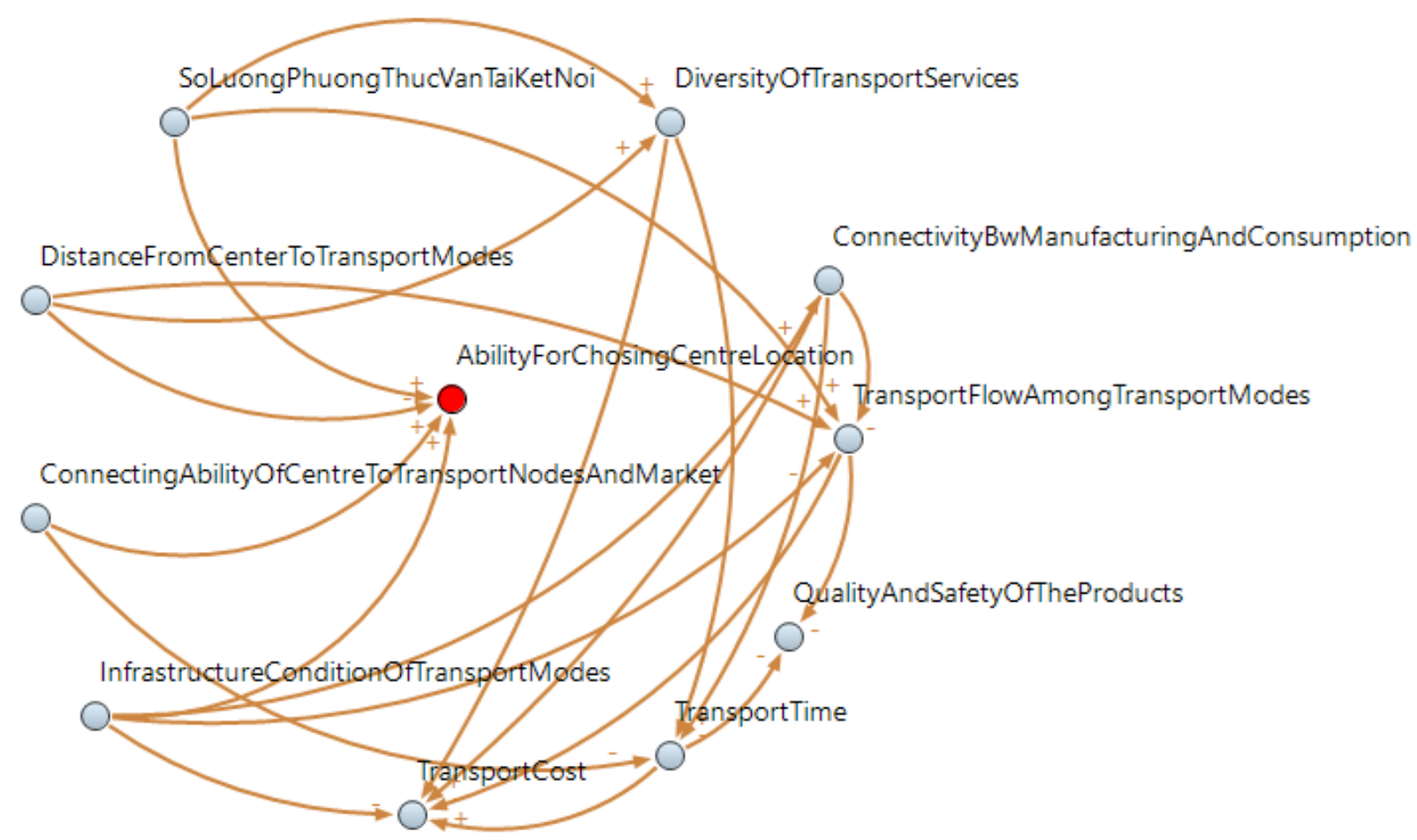

Figure 7: Relations between multimodal transport and LC

Figure 8 demonstrates causal relationships among factors (listed in Table 4) related to multimodal transport that needs to take into consideration for defining a location for LC. Regarding the connectivity, two important factors are a number of modes and the distance from each mode connecting to the center (Heydari, Govindan, \& Jafari, 2017). There are a number of questions that are raised toward this issue: what are major transport modes serving the center and whether they serve domestic or import-export products. If the import-export market is the case, cargo is mainly carried via seaway (80\%) and airway (20\%). Whereas, road transport is the optimal choice for the domestic market (Athirah, Musa, \& Keng, 2019). Besides, we need to consider the demand for using transport modes of local logistics service companies for the decisionmaking process (Alsayah, Hatf, Aboaltabooq, Majeed, \& Al-najafy, 2019).

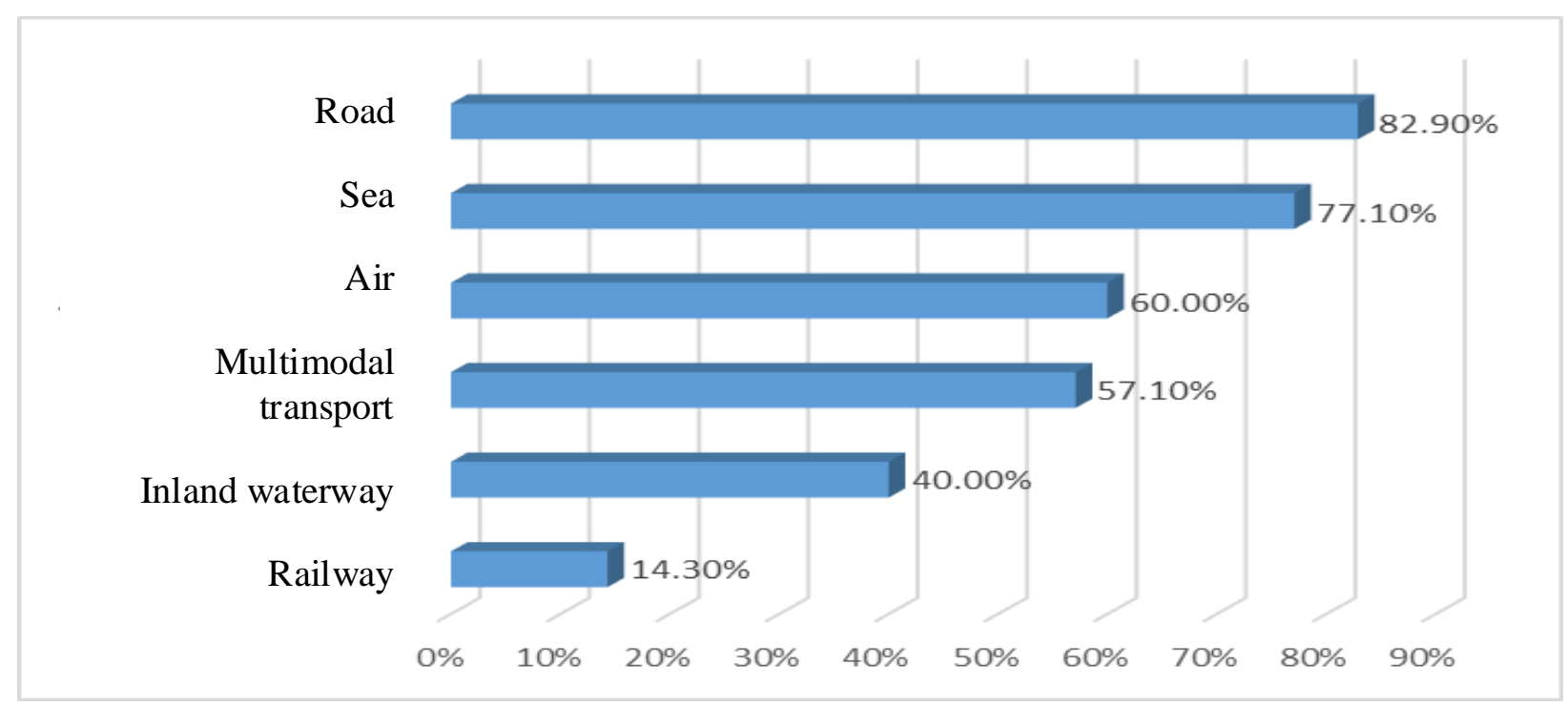

Figure 9: Current status of using transport services of LSP in SouthEast of Vietnam in 2019

Source: Survey in 2019

As can be seen from Figure 10, the highest demand in road transport is used by $82.9 \%$ of responses because of its flexibility in meeting the demand for supply for production and consumption. It is also an important linkage between other modes. Sea and air transport are popular modes of transport according to $77.1 \%$ and $60 \%$ of responses, respectively. Whereas, inland waterway and railway are not well developed because of lack of investment although their high potentials 
in reducing the burden for road transport, traffic congestion, and transport cost. In fact, the major connection is between sea-road, sea-inland waterway, sea-rail for domestic goods and import. Logistics service providers combine connections such as sea-air, air-road, sea-inland waterway - road for exporting goods following suitable season-based tariffs.

The number of transport means contributes to the variety of transport services and the betterment of good flow. Additionally, customers have more choices with transport services in accordance with their demand, optimize transport costs and ensure their goods' safety. Connecting distance and ability affect directly to the transport time from the LC to market locations. According to the in-depth interview with logistics service providers, the operation of LC needs to be ensured by connection to transport nodes like seaports, airports, highway, inland waterways, railway stations, and production locations in order to supply materials and transport goods to LC for processing before consumption. Therefore, important factors of LC are closeness to economic areas, consumption areas like industrial zones, distribution areas, wholesales markets, markets of neighboring countries. Furthermore, there is a need for the connection of LC to the subsidiary industry to support the operation of LC like pallet production or residential areas for human resource supply.

\section{CONCLUSION}

The system gives an insight into how all factors analyzed interconnect together. Once an LC is built, it can contribute significantly to the reduction of various costs, boost completeness, make the most of the capability of user enterprises, and create better connection and value for outsourcing service providers. In order to meet the demand of both cargo owner companies and logistics service providers, there could be a need for significance in the initial investment from the government and investors.

\section{THE IMPLICATIONS OF THIS STUDY AND FINDINGS}

As defined by the scope of the project, the SD model provides a qualitative demonstration of the interaction among factors. The built model gives a systematic insight into how factors link to each other. There is no quantitative interaction is taken into consideration among the factors. Further research is encouraged to take into consideration the quantitative attribute of causality among factors.

\section{ACKNOWLEDGMENTS}

Authors would like to acknowledge the industry experts, logistics service users and researchers as advisors of this research, and we are gratefully indebted to them for their very valuable comments on this research. Authors especially thank the Ho Chi Minh City University of Transport for the funding and support.

\section{REFERENCES}

1. Achachlouei, M. A., \& Hilty, L. M. (2015). Modeling the effects of ict on environmental sustainability: revisiting a system dynamics model developed for the European Commission. In ICT Innovations for Sustainability (pp. 449-474). Springer. https://doi.org/10.1007/978-3-319-09228-7_27

2. Acharya, N., Nanda, P., Panda, S., \& Acharya, S. (2018). Biodiesel from Non-Edible Vegetable Oils: A Review on Engine Performance and Emission Characteristics. Nature Environment and Pollution Technology, 17(3), 711720 .

3. Al Sahlani, A., \& A. Eidan, A. (2018). Controllable Vibrating System To Enhance the Performance of Heat Pipe Evacuated Tube Solar Collector. Journal of Mechanical Engineering Research and Developments, 41(3), 67-73. https://doi.org/10.26480/jmerd.03.2018.67.73

4. Alsayah, A. M., Hatf, M., Aboaltabooq, K., Majeed, M. H., \& Al-najafy, A. A. (2019). Multiple modern methods for improving photovoltaic cell efficiency by cooling : a review. Journal of Mechanical Engineering Research and Developments, 42(4), 71-78. https://doi.org/10.26480/jmerd.04.2019.71.78

5. Aparna, K., \& Ramakrishna, K. (2018). A review on mechanical losses and non-uniform expansion of fluid in a Scroll expander. Journal of Mechanical Engineering Research and Developments, 41(1), 9-19.

6. Athirah, N., Musa, B., \& Keng, L. (2019). Challenge of Malaysia Port toward Shipping Revolution. International Journal of E-Navigation of Maritime Economy, 12, 55-63.

7. Barata, J., Rupino Da Cunha, P., \& Stal, J. (2018). Mobile supply chain management in the industry 4.0 era: an annotated bibliography and guide for future research. Journal of Enterprise Information Management, 31(1), 173192. https://doi.org/10.1108/JEIM-09-2016-0156

8. Bukova, B., Brumercikova, E., Cerna, L., \& Drozdziel, P. (2018). The Position of Industry 4.0 in the Worldwide Logistics Chains. LOGI-Scientific Journal on Transport and Logistics, 9(1), 18-23. https://doi.org/10.2478/logi2018-0003

9. Chen, C., Tabssum, N., \& Nguyen, H. P. (2019). Study on Ancient Chu Town Urban Green Space Evolution and Ecological and Environmental Benefits. Nature Environment and Pollution Technology, 18(5), 1733-1738.

10. Dinh, G. H., \& Im, N.-K. (2016). The combination of analytical and statistical methods to define the polygonal ship domain and reflect human experiences in estimating dangerous areas. International Journal of E-Navigation and Maritime Economy, 4, 97-108. https://doi.org/10.1016/j.enavi.2016.06.009

11. Fan, J., Wang, D., \& Kang, L. (2018). Development of renewable biomass energy by catalytic gasification: 
Syngas production for environmental management. Energy Sources, Part A: Recovery, Utilization, and Environmental Effects, 40(24), 2941-2947. https://doi.org/10.1080/15567036.2018.1514435

12. Fontes, C. H. de O., \& Freires, F. G. M. (2018). Sustainable and renewable energy supply chain: A system dynamics overview. Renewable and Sustainable Energy Reviews, 82, $247-259$. https://doi.org/10.1016/j.rser.2017.09.033

13. Garza-Reyes, J. A., Villarreal, B., Kumar, V., \& Molina Ruiz, P. (2016). Lean and green in the transport and logistics sector-a case study of simultaneous deployment. Production Planning \& Control, 27(15), 1221-1232. https://doi.org/10.1080/09537287.2016.1197436

14. Gligor, D., Tan, A., \& Nguyen, T. N. T. (2018). The obstacles to cold chain implementation in developing countries: insights from Vietnam. The International Journal of Logistics Management, 29(3), 942-958. https://doi.org/10.1108/IJLM-02-2017-0026

15. Gobinath, S., Senthilkumar, G., \& Beemkumar, N. (2018). Air nanobubble-enhanced combustion study using mustard biodiesel in a common rail direct injection engine. Energy Sources, Part A: Recovery, Utilization, and Environmental Effects, 1-8. https://doi.org/10.1080/15567036.2018.1549159

16. Golroudbary, S. R., \& Zahraee, S. M. (2015). System dynamics model for optimizing the recycling and collection of waste material in a closed-loop supply chain. Simulation Modelling Practice and Theory, 53, 88-102. https://doi.org/10.1016/j.simpat.2015.02.001

17. Guo, S., Shen, B., Choi, T.-M., \& Jung, S. (2017). A review of supply chain contracts in reverse logistics: Supply chain structures and channel leaderships. Journal of Cleaner Production, 144, 387-402. https://doi.org/10.1016/i.jclepro.2016.12.112

18. Hazen, B. T., \& Ellinger, A. E. (2019). Special issue editorial: logistics customer service revisited. International Journal of Physical Distribution \& Logistics Management, 49(1), 2-3. https://doi.org/10.1108/IJPDLM-02-2019$\underline{373}$

19. Heydari, J., Govindan, K., \& Jafari, A. (2017). Reverse and closed-loop supply chain coordination by considering government role. Transportation Research Part D: Transport and Environment. https://doi.org/10.1016/j.trd.2017.03.008

20. Hidayati, N., Karim, A., Haqimin, N., Salleh, M., \& Harun, M. (2019). Maritime Terrorisms and Navigational Security in the Sulu Sea. International Journal of E-Navigation of Maritime Economy, 12, 42-54. https://doi.org/10.1017/9781108594516.003

21. Hou, F., Peng, P., \& Cai, T. (2017). Can Government Green Procurement Promote Green Technology Innovation - Take Beijing as an example. Journal of Mechanical Engineering Research and Developments, 40(1), 110-116.

22. Huber, S., Klauenberg, J., \& Thaller, C. (2015). Consideration of transport logistics hubs in freight transport demand models. European Transport Research Review, 7(4), 32. https://doi.org/10.1007/s12544-015-0181-5

23. Jeevan, J, Salleh, N. H. M., Loke, K. B., \& Saharuddin, A. H. (2017). Preparation of dry ports for a competitive environment in the container seaport system: A process benchmarking approach. International Journal of ENavigation and Maritime Economy, 7, 19-33. https://doi.org/10.1016/j.enavi.2017.06.003

24. Jeevan, Jagan, M.R, O., A.H, S., G.K, P., \& T.M.H, D. (2018). An Evolution of a Nexus between Malaysian Seaport Centric Logistic and An Evolution of a Nexus between Malaysian Seaport Centric Logistic and. International Journal of E-Navigation of Maritime Economy, 10(April 2019), 01-015.

25. Kaewunruen, S., Sussman, J. M., \& Matsumoto, A. (2016). Grand challenges in transportation and transit systems. Frontiers in Built Environment, 2, 4. https://doi.org/10.3389/fbuil.2016.00004

26. Kamble, S. S., Gunasekaran, A., \& Gawankar, S. A. (2018). Sustainable Industry 4.0 framework: A systematic literature review identifying the current trends and future perspectives. Process Safety and Environmental Protection, 117, 408-425. https://doi.org/10.1016/j.psep.2018.05.009

27. Kumar, S., Singh, A., \& Kumar, H. (2018). Assessment of tracing element characteristics of F-type fly and bottom ash mixture. Energy Sources, Part A: Recovery, Utilization, and Environmental Effects, 40(24), 29672973. https://doi.org/10.1080/15567036.2018.1514438

28. Lagorio, A., Pinto, R., \& Golini, R. (2016). Research in urban logistics: a systematic literature review. International Journal of Physical Distribution \& Logistics Management. https://doi.org/10.1108/IJPDLM-01-2016-0008

29. Li, M. (2016). Haze pollution control strategies in China from the perspective of energy conservation and emission reduction. Nature Environment and Pollution Technology.

30. Li, Y., Kannan, D., Garg, K., Gupta, S., Gandhi, K., \& Jha, P. C. (2018). Business orientation policy and process analysis evaluation for establishing third-party providers of reverse logistics services. Journal of Cleaner Production, 182, 1033-1047. https://doi.org/10.1016/j.jclepro.2017.12.241

31. Luthra, S., \& Mangla, S. K. (2018). Evaluating challenges to Industry 4.0 initiatives for supply chain sustainability in emerging economies. Process Safety and Environmental Protection, 117, $168-179$. https://doi.org/10.1016/j.psep.2018.04.018

32. Montwiłł, A. (2016). The impact of the development of seaport objective functions for a cargo logistics system in urban areas, illustrated with an example of the Szczecin Metropolis. Transportation Research Procedia, 16, 366377. https://doi.org/10.1016/j.trpro.2016.11.035 
33. Nguyen, G. N. T., \& Sarker, T. (2018). Sustainable coffee supply chain management: a case study in Buon Me Thuot City, Daklak, Vietnam. International Journal of Corporate Social Responsibility, $3(1), 1$. https://doi.org/10.1186/s40991-017-0024-X

34. Noorul, RAHMAN, \& Noor Apandi OSNIN, Rudiah MD HANAFIAH, Mohd Rahimi ABDUL HALIM, Shahriman ABDUL HAMIDc, K. (2019). Augmentation of maritime interactive teaching model towards sustainable development goal and industrial. International Journal of E-Navigation of Maritime Economy, 13, 113.

35. Panigrahi, S. K., Kar, F. W., Fen, T. A., Hoe, L. K., \& Wong, M. (2018). A Strategic Initiative for Successful Reverse Logistics Management in Retail Industry. Global Business Review, 19(3_suppl), S151-S175. https://doi.org/10.1177/0972150918758096

36. Pratiwi, L., \& Furusho, M. (2019). Analysis of Collision at Sea using Human Error Assessment and Reductive Technique (HEART) in Japan and Hong Kong. International Journal of E-Navigation of Maritime Economy, 6, 128-136. https://doi.org/10.23977/mastic.004

37. Qaiser, F. H., Ahmed, K., Sykora, M., Choudhary, A., \& Simpson, M. (2017). Decision support systems for sustainable logistics: a review and bibliometric analysis. Industrial Management \& Data Systems. https://doi.org/10.1108/IMDS-09-2016-0410

38. Qu, T., Thürer, M., Wang, J., Wang, Z., Fu, H., Li, C., \& Huang, G. Q. (2017). System dynamics analysis for an Internet-of-Things-enabled production logistics system. International Journal of Production Research, 55(9), 2622-2649. https://doi.org/10.1080/00207543.2016.1173738

39. Quandt, M., Beinke, T., Ait-Alla, A., \& Freitag, M. (2017). Simulation-Based Investigation of the Impact of Information Sharing on the Offshore Wind Farm Installation Process. International Journal of E-Navigation of Maritime Economy, 7, 042-054. https://doi.org/10.1155/2017/8301316

40. Rahman, N. S. F. A., Saharuddin, A. H., \& Rasdi, R. (2014). Effect of the northern sea route opening to the shipping activities at Malacca straits. International Journal of E-Navigation and Maritime Economy, 1, 85-98. https://doi.org/10.1016/j.enavi.2014.12.008

41. Ruina, L., Zhong, W., Peiyong, N., \& Haobin, J. (2019). Effects of exhaust gas recirculation on the particulates structure characteristics of a diesel engine fueled with diesel/biodiesel blend. Energy Sources, Part A: Recovery, Utilization, and Environmental Effects, 1-17. https://doi.org/10.1080/15567036.2019.1646351

42. Salleh, N. H. M., Alias, N. A., Jeevan, J., Hanafiah, R. M., \& Ngah, A. H. (2019). A Perspective of Malaysian Marine Training Providers and Shipowners on Communication Issues Onboard Merchant Vessels. International Journal of E-Navigation of Maritime Economy, 11, 33-43.

43. Schliwa, G., Armitage, R., Aziz, S., Evans, J., \& Rhoades, J. (2015). Sustainable city logistics-Making cargo cycles viable for urban freight transport. Research in Transportation Business \& Management, 15, 50-57. https://doi.org/10.1016/j.rtbm.2015.02.001

44. Sivaraja, C. M., Sakthivel, G., \& Warke, V. R. (2018). Selection of optimum fuel blend to empower the energy efficiency in the IC engine using the decision system. Energy Sources, Part A: Recovery, Utilization, and Environmental Effects, 40(6), 693-708. https://doi.org/10.1080/15567036.2018.1454551

45. Supply, S., Practices, C., Ain, N., Abd, S., Haqimin, N., Salleh, M., \& Jeevan, J. (2019). Compatibility Analysis of New Lean, Agile, Resilience and Green ( LARG ) Paradigm. International Journal of E-Navigation of Maritime Economy, 13, 70-83.

46. Wang, C.-N., \& Nguyen, H.-K. (2017). Enhancing urban development quality based on the results of appraising the efficient performance of investors - a case study in Vietnam. Sustainability, 9(8), 1397. https://doi.org/10.3390/su9081397

47. Witkowski, K. (2017). Internet of things, big data, industry 4.0-innovative solutions in logistics and supply chain management. Procedia Engineering, 182, 763-769. https://doi.org/10.1016/j.proeng.2017.03.197

48. Xia, P., Liu, F., Xin, M., Guo, Y., Chen, Y., Yu, C., \& Ma, J. (2017). Dynamic Correction SOC Estimation Method Based on Real Vehicle Analysis Battery Characteristics. Journal of Mechanical Engineering Research and Developments, 40(4), 633-638. https://doi.org/10.7508/jmerd.2017.04.011

49. Yang, B., Song, G., Shen, L., Ghuktomova, Y. A., \& Xu, J. (2017). Fault Diagnosis Method for Internal Combustion Engines Based on IHS-RVM Model. Journal of Mechanical Engineering Research and Developments, 40(1), 64-71.

50. Yaqiong, L. V, Lei, T. U., LEE, C. K. M., \& Xin, T. (2018). IoT based Omni-Channel Logistics Service in Industry 4.0. In 2018 IEEE International Conference on Service Operations and Logistics, and Informatics (SOLI) (pp. 240-243). IEEE. https://doi.org/10.1109/SOLI.2018.8476708

51. Yesilyurt, M. K. (2018). The evaluation of a direct injection diesel engine operating with waste cooking oil biodiesel in point of the environmental and enviroeconomic aspects. Energy Sources, Part A: Recovery, Utilization, and Environmental Effects, 40(6), 654-661. https://doi.org/10.1080/15567036.2018.1454546

52. Yoon, D.-G., \& Doan, T. B. T. (2018). A Study of the Logistics Development in Hai Phong Port. Journal of Korean Navigation and Port Reserch, 42(2), 137-142.

53. Yu, B., \& Wu, S. (2017). A branch model simulation for express logistics service system evaluation under online shopping. In 2017 4th International Conference on Systems and Informatics (ICSAI) (pp. 773-778). IEEE. 
https://doi.org/10.1109/ICSAI.2017.8248390

54. Zainal, Z., \& Jeevan, J. (2019). The Evolution of Seaport Competitiveness in Malaysia Seaport System. International Journal of E-Navigation of Maritime Economy, 12, 100-110.

55. Zhang, Q., Jiang, N., Hu, Y., \& Pan, D. (2017). Design of Course-Keeping Controller for a Ship Based on Backstepping and Neural Networks. International Journal of E-Navigation and Maritime Economy, 7, 34-41. https://doi.org/10.1016/j.enavi.2017.06.004 